\title{
The Study of Teacher Role in Writing 3 Class at the English Department of Petra Christian University
}

\author{
Carmelia Avelyne Nancy Lay \\ English Department, Faculty of Languages and Literature, Petra Christian University, Siwalankerto 121-131, \\ Surabaya 60236, INDONESIA \\ Emails: carmelialay@gmail.com
}

\begin{abstract}
In this study, the writer discussed types of teacher role in Writing 3 class at English Department of Petra Christian University. The purpose of this study was to find out the types of teacher roles and different treatments between regular and repeater students. The subject of this study was a lecturer teaching Writing 3 class at English Department of Petra Christian University. The theories used by the writer were types of teacher roles in writing class by Harmer (2007) and Richards (2015). The writer used classroom observation and video recording to collect the data. The findings of this study revealed that there were eight types of teacher role out of nine seen in Writing 3 class which were resource/facilitator, feedback provider/evaluator, motivator, expert writer, cultural informant, collaborator, investigator, and problem solver. As for the treatment, there were different treatments between regular and repeater students. From this study, it could be concluded that the teacher played eight roles out of nine types of teacher roles based on what the students needed and the teacher gave more attention to the repeater students.
\end{abstract}

Key words: Teacher roles, repeater students, regular students, treatment

\section{INTRODUCTION}

Writing is seen as crucial anywhere (Aims Community College, 2018). Therefore, writing class is important nowadays since writing is required all the time (Mendes, 2018), especially students who study in universities. However, students always deal with essays in their academic institution not without difficulties. When writing is seen as important yet a complex, recursive and creative process, and learning to write requires the development of an efficient and effective composing process (Silva and Matsuda, 2002), teacher roles have a big impact in learning and teaching process. In this modern era, writing teachers have to play different roles in their classes. According to Harmer (2007), writing teachers have three different roles namely motivator, resource, and feedback provider. In line with this, Richards (2015) states that writing teachers have eight roles which are facilitator, expert writer, cultural informant, collaborator, audience, investigator, problem solver, and evaluator. From those roles, the writer combined some roles that have the same function. The role as resource by Harmer (2007) is combined with the role as facilitator by Richards (2015). Then, the role as feedback provider by Harmer (2007) is combined with the role as evaluator by Richards (2015). So, the total of the roles become nine roles.

In this study, the writer wanted to identify the types of teacher role seen in Writing 3 Class. The role of teacher can be seen through the conversation between the teacher and the students. However, the writer only focused on teacher talk in Writing 3 class to identify the types of teacher role. Since in this class there were repeater students besides the regular ones (those who do not retake the writing 3 class), the writer also indentified types of teacher role played with per student, especially the repeater students so that the writer could see whether there are any the different treatments between them.

\section{METHODS}

This study was qualitative because the writer did observations to collect the data and recorded the activities in the class. The data analysis was done with words and the result of this study was the writer's understanding of the data.

In order to collect the data, the writer did some steps. First, the writer asked permission letter from English Department administration office. After that, the writer met the teacher to ask 
permission to observe her class and record the class using video recorder. After getting permission from English Department administration office and the writing 3 teacher, the writer did the observation. The writer did the observation four times.

In doing the observations, the writer used a video recorder to record the all teaching and learning activities conducted by the teacher of the writing class. The writer recorded the first four meetings. However, the writer only analyzed two meetings because there was not much discussion in third meeting and fourth meeting. The duration of the meeting was one hour and forty minutes. The writer collected the data from the mid-August until mid-September of 2018. The writer did a non-participant observation in the class successively every week. In order to collect the data, the writer also used observation protocol seen in the table below to collect the data. In addition, the writer used detailed transcription for the observation. The details of the data include all utterances, pauses, silent, etc (Elliot, 2005). The writer used detailed transcription because the detailed transcription can show a clearer context for the analysis.

Table 1. The Observation Protocol for Teacher Roles in the Classroom

\begin{tabular}{|c|c|c|c|c|}
\hline & & Observ & on Protocol & \\
\hline Name & course: & & Name of & \\
\hline Class & & & Topic: & \\
\hline Class & igth: & minutes & Total nun & udents: \\
\hline Time & Activity & Teacher Activities & Students Activities & Notes \\
\hline
\end{tabular}

Then, after transcribing, the writer gave boldface for teacher talk in the class that contained teacher roles. The purpose of giving boldface was to make the writer easier to analyze teacher talk so that the writer could see the types of teacher role seen in teacher talk. The writer more focused on the teacher talk in order to find out the types of teacher role played in the class. In the analysis, the writer analyzed the overall conversation and the conversation between the teacher and per student as well. The writer wanted to find out the types of teacher role applied for each student so that the writer could see different treatments between regular students and repeater students. Although the writer more focused on analyzing teacher talk, the writer also put student talk in the analysis to give clearer context of what was happening in the class and what the students' needs were to make the writer easier to conclude the types of teacher role played for each student.

Next, the writer applied numbering system for teacher talk and students talk for each table. In the table analysis for classroom observation, the numbering systems are 1.1 and 2.1. The first digit 1.1 represents teacher talk in the first meeting and the second digit 2.1 represents teacher talk in the second meeting. Then, the writer put the code number in table 1 . The writer organized the teacher talk and student talk in turn taking to make it relate to one another. In the table, to analyze each student, the writer gave bold on the code number and the student number to differentiate which student that was analyzed. In addition, the writer also put $\mathrm{Sn} 1, \mathrm{Sn} 2$, and $\mathrm{Sn} 3$ for the sentences that were analyzed in teacher talk.

Table 2. The Key Characteristics of each Type of Teacher Roles in Writing Class

\begin{tabular}{|l|l|ll|}
\hline No. & \multicolumn{1}{|c|}{ Teacher Role } & \multicolumn{1}{c|}{ Example } \\
\hline 1. & Resource/facilitator (R/F) & $\begin{array}{l}\text { - Supplying sources } \\
\text { - Giving information to find the sources. } \\
\text { Giving advice about language. (It can be vocabulary, text } \\
\text { formation, or phrase) }\end{array}$ \\
\hline 2. & $\begin{array}{l}\text { Feedback provider/evaluator } \\
\text { (FP/E) }\end{array}$ & $\begin{array}{l}\text { Giving suggestion about language } \\
\text { Correcting students' writing about what or how to focus on } \\
\text { the topic and content }\end{array}$ \\
\hline 3. & Motivator $(\mathrm{M})$ & $\begin{array}{l}\text { Giving suggestion: giving ideas for improvement related to } \\
\text { content }\end{array}$ \\
\hline
\end{tabular}




\begin{tabular}{|c|c|c|}
\hline & & - $\quad$ Encouraging the students in writing \\
\hline 4. & Expert writer (EW) & $\begin{array}{l}\text { - Giving information about the features of new genre or text } \\
\text { types to students } \\
\text { - } \quad \text { Explaining the organization of the text } \\
\text { - } \quad \text { Giving some advice what should be written }\end{array}$ \\
\hline 5. & Cultural informant (CI) & $\begin{array}{l}\text { - } \quad \text { Giving information related to social or cultural context } \\
\text { - } \quad \text { Telling the students their expectation readers are }\end{array}$ \\
\hline 6. & Collaborator $(\mathrm{C})$ & $\begin{array}{l}\text { - } \quad \text { Working together with students to gather ideas from sharing } \\
\text { - } \quad \text { Solving problems together with the students }\end{array}$ \\
\hline 7. & Audience $(\mathrm{A})$ & - Becoming the students' text reader \\
\hline 8. & Investigator (I) & $\begin{array}{l}\text { - Investigating the students' learning } \\
\text { - } \quad \text { Investigating the student's problems }\end{array}$ \\
\hline 9. & Problem solver (PS) & - $\quad$ Solving the students' problem after knowing the problems \\
\hline
\end{tabular}

In order to help the writer doing the analysis, the writer used the key characteristics to know what types of teacher role that contained in teacher talk. These key activities helped the writer to understand what types of teacher role seen in the teacher talk based on these key activities that the teacher did in the class.

\section{FINDINGS AND DISCUSSION}

In this chapter, the writer divided the discussion into two parts in order to answer the research questions. The first part is about the types of teacher role played in writing class. The second part is the different treatments between regular students and repeater students.

\section{Types of Teacher Role seen in Writing Class 3}

The whole finding of types of teacher role seen in Writing 3 class is summarized in the following table.

Table 3. The Whole Findings of the Types of Teacher Roles in Writing 3 class

\begin{tabular}{|l|c|c|}
\hline \multicolumn{1}{|c|}{ Teacher Role } & First Meeting & Second Meeting \\
\hline Resource/Facilitator & $\checkmark$ & $\checkmark$ \\
\hline Feedback provider/Evaluator & $\checkmark$ & $\checkmark$ \\
\hline Motivator & $\checkmark$ & $\checkmark$ \\
\hline Expert writer & $\checkmark$ & $\checkmark$ \\
\hline Cultural informant & - & $\checkmark$ \\
\hline Collaborator & $\checkmark$ & - \\
\hline Audience & - & $\checkmark$ \\
\hline Investigator & $\checkmark$ & $\checkmark$ \\
\hline Problem Solver & $\checkmark$ & $\checkmark$ \\
\hline
\end{tabular}

From the table above, it could be seen that the teacher played eight types of teacher role based on Harmer (2007) and Richards (2015).

Firstly, as a resource/facilitator, the teacher gave advice, suggestion, or resource related to students' writing tasks when the students needed information or language. In addition, the teacher also had to discover resources for the students. For example: When the teacher said "and noisy, noisy also has negative connotation right? If you say it's more alive then it shows good connotation", the teacher was acting as resource/facilitator. The teacher explained that the word "noisy" that the student used for the student's writing has negative connotation. Then, the teacher suggested a word that is better to use instead of "noisy". By giving suggestion word to the student, the teacher's role was as a resource/facilitator. Mostly in this role, the teacher as a resource/facilitator would pay attention to the students' language. If there was a problem related to language, the teacher would give advice or suggestion. In addition, the teacher also gave information about language, like definition of a word.

Next, when the teacher acted as feedback provider/evaluator, the teacher evaluated or gave feedback to the students writing by giving responses to the content of students' writing, including corrections and suggestions for improvement. For example: the teacher said "so actually you've 
mentioned the more complete one, you said there was an infrastructure upgrade, I think that would be a better topic sentence than that because it's more specific to your point. Would be better if you use it". Here from the teacher talk, the teacher gave suggestion on the content of the student writing and which one the student should focus on. Therefore, the talk showed that the teacher acted as feedback provider/evaluator. In this role, the teacher paid attention more to the content of the students' writing. When seeing the students had problems with the content, the teacher directly acted as feedback provider/evaluator by giving correction and suggestion to the students so that they could improve their writing.

Then, when the teacher played her role as motivator, the teacher created activities to motivate the students to generate ideas from the activities. The teacher also encouraged the student in doing their writing until the students finished writing. For instance in the teacher talk, the teacher said "it's just an outline, so don't over think it. If you think it's hard, just raise your hand and ask. If you're too shy to ask publicly, I'll come to your place". In the situation, while the students writing their outline, the teacher tried to give motivation for the student so that the students would be braver to ask, if they had problems and made sure the students were not under pressure doing the outline. Thus, the teacher acted as motivator by motivating the students in the process of their writing. In motivating the students, mostly the teacher would make or create activities such as exercise and game. In addition, the teacher also motivated the students through her encouraging words so that the students were motivated enough to write.

Then, being an expert writer, what that the teacher did in the writing class was basically telling and explaining to the students how the students' writing should be organized. The teacher also explained to the students what features that should be given to their writing and what should be written in a text. For instance from the teacher talk "Now, the majority of compare and contrast essay will be in simple present tense. Pretty essay, right? However, if you're retelling something from the past, for instance, you compare..." it was clear that the teacher explained the feature of a compare and contrast essay. Therefore, the teacher acted as an expert writer by giving information about the feature of the text. In addition, acting as an expert writer, the teacher explained more about the feature of the text and the organization of the text. Before the students started writing their essay, it was a very useful explanation for the students so that they can know that every text type has their own features and organization.

The role of cultural informant was not really played by the teacher. However, this role could be seen if the teacher helped the students understand things related to social context and cultural context. It could be seen from the example of this teacher talk: "no? ok... so, if you think of this city is the best destination for tourism, what would be the first factor for you? Is the best vacation city in the world, why? When you think of... let's say, you think that Paris why would you think that way? What's the first consideration?". In this situation, the teacher was helping the student to think about the social context of tourism. She tried to make the student think why the city is good for tourism and why people choose the city. In addition, one of the jobs of cultural informant is helping students to understand social context. Therefore, in this teacher talk, it could be seen that the teacher acted as a cultural informant. For this role, the writer only found two from the analysis. Basically what the teacher should do in this role is just giving information related to social and cultural context, and expectation readers for a text. However, to identify this role, it also depends on students writing whether they write something related to social and cultural context, if not it could be very rare to find.

When playing the role as a collaborator, the teacher basically asked the students to work or think together to gather new ideas for their writing task. They could get the ideas from sharing; that was why not only the teacher gave advice, inputs, or suggestions to the students but also she asked the whole class to give advice, inputs, or suggestion for their friends. The example of teacher role as motivator could be seen from this teacher talk: "alright? Any suggestion? Any input? [asking the whole class]." The teacher talk showed that the teacher was asking the other students to participate in giving suggestion or input for their friends. Thus, the teacher role played in this part was the teacher as a collaborator. In this role, in order to gather ideas, the teacher asked suggestions from the students so that they could help each other. Not only the teacher gave suggestion to the students, but also they could work together to get more suggestions. Therefore, the teacher played her role as a collaborator. 
Next, as an investigator, the teacher usually asked questions to investigate the students' learning and the process of writing. It could be problems that the students faced while writing or why the students wrote that way, etc. For example, when the teacher said "so you want to focus on the media garden, but what do you mean exactly by the room for public because it's not really representative for aaa of your supporting", it showed that the teacher investigated the student's writing by asking what the student meant. The teacher did it because she found out that there was a problem with the student's writing. By asking the question, the teacher played her role as investigator. For this role, mostly the teacher would ask questions related to students' writing and the students' learning. The questions basically were about why the students think that way or why the students write that way, or what the students have learned etc.

Lastly, when acting as a problem solver, the teacher had to know the students' problem first whether it is a problem in the content, form, or organization. After knowing the student's problem, the teacher will help the students to solve the problem. The example from the teacher talk was "I'm afraid what you mention here, maybe repeated here. So, this point is a problem. So, you can combine one and three". From the example of the teacher talk, when the student had a problem with his topic sentence, the teacher gave advice to the student to combine his topic sentence one and three. Therefore, the teacher here acted as a problem solver. For this role, the teacher usually gave advice or suggestions to help the students to solve their problems. Usually the teacher had to find out the problems first. After finding the problem, the teacher would solve the problem directly to the students.

Based on the findings explained above, there were only eight types of teacher role played in the writing 3 class. There was one teacher role which was not played by the teacher in the class namely audience. The function of the teacher as audience was becoming the person students write to. The teacher actually played the role, but the role was not seen in the teacher talk. It was not because the role was not used, but it was because the teacher did not directly say that she was the person who read the student writing. In addition, those roles played by the teacher in the writing class were because mostly in the classroom the teacher focused on explaining, observing, giving advice or suggestion, and helping the students while writing instead of saying to the students' that she was the person who read the students' writing.

\section{Different Treatment between Regular Students and Repeater Students}

In the writing class, there were repeater students and regular students. In the first meeting there was one student who did not attend the class. The student was student 7 . The writer used the table below to show the different treatments to each student.

Table 4. The Types of Teacher Role between Regular and Repeater Students in Meeting 1

\begin{tabular}{|c|c|c|c|c|c|c|c|c|c|c|c|c|c|}
\hline \multirow[t]{2}{*}{ No. } & \multirow[t]{2}{*}{ Teacher Role } & \multicolumn{6}{|c|}{ Regular students } & \multicolumn{6}{|c|}{ Repeater Students } \\
\hline & & S1 & S3 & $\mathrm{S} 4$ & S5 & S8 & Total & S2 & S6 & S7 & S9 & $\mathrm{S} 10$ & Total \\
\hline 1. & Resource/facilitator & 2 & 1 & & 2 & & 5 & & & & 1 & & 1 \\
\hline 2. & Feedback provider/evaluator & & & & & & & & & & 1 & & 1 \\
\hline 3. & Motivator & 1 & & 1 & & 1 & 3 & 1 & & & & & 1 \\
\hline 4. & Expert writer & & & & & & & & & & & & \\
\hline 5. & Cultural informant & & & & & & & & & & & & \\
\hline 6. & Collaborator & & & & & & & & & & & & \\
\hline 7. & Audience & & & & & & & & & & & & \\
\hline 8. & Investigator & & & & 2 & 1 & 3 & 2 & & & 2 & 1 & 5 \\
\hline 9. & Problem solver & & & & & & & & & & & & \\
\hline
\end{tabular}

In meeting one, there was no significant different treatment that could be seen because the activity in the class was just about introduction and exercise. In the exercise, the teacher asked the students to present their outline one by one. From it, the teacher started to play her roles with each student. Basically, the teacher played her roles based on what the students presented. The types of teacher role played in meeting one were resource/facilitator, motivator, and investigator, and feedback provider/evaluator.

For regular students, the dominant role played by the teacher was resource/facilitator in which the teacher played it five times in total. It was because mostly the students needed more information about language and words. Then, the teacher also played her role as motivator three 
times because after the student done good writing, the teacher motivated the students by saying encouraging words. The last role that the teacher played was investigator and it occurred three times. When the students did not give clear explanation about their outline, the teacher acted as a investigator to ask the student to make it clear.

Investigator was also the dominant role played by the teacher and it occurred five times. When the repeater students' presented their outline, it was not really clear and confusing; that was why the teacher played more her role as an investigator to ask for clarification and to know what the students meant. Then, the teacher also acted as resource/facilitator, feedback provider, and motivator one time.

In conclusion, there was no significant treatment between regular and repeater students in meeting 1 since the teacher only played some roles based on what the students presented. The difference only the dominant roles in which the teacher played her role as resource/facilitator with regular students while with repeater students the teacher played investigator.

However, in meeting two, it could be seen that there was different treatment between regular and repeater students. The difference treatment could be seen in the table from the total/frequency use of each role played by the teacher when facing each student. The frequency total roles seen in repeater students were used more than regular students.

Table 5. The Types of Teacher Role between Regular and Repeater Students in Metting 2

\begin{tabular}{|l|l|c|c|c|c|c|c|c|c|c|c|c|c|}
\hline No. & Teacher Role & \multicolumn{9}{|c|}{ Regular students } & \multicolumn{6}{|c|}{ Repeater Students } \\
\cline { 3 - 14 } & & S1 & S3 & S4 & S5 & S8 & Total & S2 & S6 & S7 & S9 & S10 & Total \\
\hline 1. & Resource/facilitator & 1 & & & 2 & 1 & 4 & 2 & & 1 & 1 & 1 & 5 \\
\hline 2. & $\begin{array}{l}\text { Feedback } \\
\text { provider/evaluator }\end{array}$ & 1 & 1 & & & 1 & 3 & 2 & & & 3 & 1 & 6 \\
\hline 3. & Motivator & & & & & & & & 1 & & 1 & 1 & 3 \\
\hline 4. & Expert writer & 1 & & & & & 1 & 2 & & & & & 2 \\
\hline 5. & Cultural informant & & & & & & & & & & 2 & & \\
\hline 6. & Collaborator & 2 & 2 & & 2 & 1 & 7 & 2 & & 2 & 2 & 1 & 7 \\
\hline 7. & Audience & & & & & & & & & & & & \\
\hline 8. & Investigator & & 1 & & 2 & & 3 & 2 & & & 4 & & 6 \\
\hline 9. & Problem solver & & & & 1 & & 1 & & & 1 & 2 & & 3 \\
\hline
\end{tabular}

For resource/facilitator, the teacher played the role four times with regular students and five times with repeater students. The difference was not really seen because almost of the students needed information, advice, and suggestion about language, but still the total use of the role was more towards repeater students.

For feedback provider/evaluator, it was played three times with regular students while with repeater students it was played six times. From the total, it could be seen that the repeater students had more problem with the content of their writing; that was why the teacher played her role more towards repeater students.

Then, the role as a motivator was played once with regular students whereas with repeater students it was played three times. In order to encourage the repeater students to do better, the teacher motivate the student with motivating words so that the students were motivated enough to improve their writing. It was the reason why the teacher played the role as a motivator more to repeater students.

The role of expert writer appeared one time with regular students and two times with repeater students. Here, even though the difference total was only one, the difference total showed that the teacher helped the repeater student more than regular students.

For the role as a cultural informant, it was played two times with of the repeater students. It was really clear that only the repeater student needed information from the teacher about social context; that was why the teacher played her role as cultural information to help the student. In this case, it also showed that the role was used only to help repeater student instead of regular student.

Next, the total use of the role as collaborator was the same between regular and repeater students. The teacher played the role as a collaborator equally because the discussions in the two meetings 
were between the teacher and the students in which the teacher wanted to work together with all the students to get more input, suggestion, advice, etc.

The teacher as an audience was not seen in the first and second meeting. In fact, the teacher actually played the role, but the role was not seen in the teacher talk. It was not because the role was not used, but it was because the teacher did not directly say that she was the object of the student writing. The function of the teacher as audience was becoming the person students write for.

For investigator, the total use of the role was three times with regular students and six times with repeater students. The reason why the total use of the role was dominant towards repeater students was because the teacher found out that repeater students' writings were not really clear and in order to know what actually the students wrote, the teacher played the role to investigate the students.

Lastly, as a problem solver, the teacher played the role one time with regular student and three times with repeater students. So, the teacher played the types of teacher roles more frequent with repeater students than with regular students. It was because the teacher found out more problems faced by repeater students than regular students.

Based on the types of teacher role found in the teacher talk in meeting 2 when the teacher had discussion with each student one by one, it could be seen that the teacher played more roles towards repeater students. The teacher played more roles towards repeater students when finding problems that the students had related to their writing. The dominant roles played by the teacher were resource/facilitator and feedback provider/evaluator. It was because the students had more problems with their language and the content of their writing. In addition, there was one dominant role as well which was collaborator because in the activity, the teacher worked together with all the students to help each other in giving inputs or feedbacks. The teacher did not really play many roles to the regular students since the regular students' writing did not have many mistakes. In conclusion, although all the roles are important for all students' when they wrote their essay, it cannot be denied that the teacher gave more attention to repeater students.

In meeting 2, the different treatment could be seen not only in the total/frequency use of each role played by the teacher when facing each student, but also the activity in meeting 2 was about working together with the students to discuss their outline while in meeting one, the activity was just about introduction and practice.

For the findings overall, those roles, resource/facilitator, feedback provider/evaluator, motivator, expert writer cultural informant, and collaborator were used in accordance with the students' need. All the roles were very useful for the student to do their writing. In addition, when it came to the different treatments, the repeater students need more treatment or attention than regular students.

\section{CONCLUSION AND DISCUSSION}

From the analysis of the writing class, the writer found eight out of nine types of teacher role in the class. Those roles were found in the meetings seen through the teacher talk. One role that did not appear in the teacher talk was audience. It was not because the role was not played by the teacher, but because the teacher did not directly say that she was the person to whom the students write. In addition, the writer found out that there were different treatments between regular students and repeater. The teacher played more roles towards repeater students to help the students' writing, while for regular students; the teacher only played some roles. The teacher played more roles towards repeater students based on the students' writing and the students' explanations when having discussion with the teacher. The teacher needs to pay attention more or give special attention to repeater students since they need more help to improve their writing.

\section{REFERENCES}

Aims Community College. (2018). Why Writing Is Important. Retrieved September 10, 2018, from https://www.aims.edu/student/online-writing-lab/oberview/why.php

Elliott, J. (2005). Using narrative in social research: Qualitative and quantitative approaches. London, UK: sage Publication, Ltd.

Harmer, J. (2007). The Practice of English Language Teaching (4th Ed.). London: Longman.

Mendes, R. (2018). The Importance of Writing Classes. Retrieved November 13, 2018, from http://seda.college/the-importance-of-writing-classes/ 
Richards, J. (2015). Key Issues in Language Teaching. Cambridge: Cambridge University Press. Silva, T. and Matsuda, P. Q. (2002). 'Writing'. In N. Schmitt (ed.) An Introduction to Applied Linguistics, London: Arnold, pp. 252-66. 